\title{
Forklifts, Automated Guided Vehicles and Horizontal Order Pickers in Industrial Environments. Energy Management of an Active Hybrid Power System based on Batteries, PEM Fuel Cells and Ultracapacitors.
}

\author{
J.S. Artal-Sevil, J.L. Bernal-Agustín, R. Dufo-López and J.A. Domínguez-Navarro \\ Department of Electrical Engineering. \\ EINA Escuela de Ingeniería y Arquitectura. University of Zaragoza. \\ Campus Río Ebro - 50018 Zaragoza (Spain) \\ Phone/Fax number: +0034 976 762823, e-mail: jsartal@unizar.es
}

\begin{abstract}
The renewable energies together with other technologies in low $\mathrm{CO}_{2}$ emissions and the efficiency must be the base of the most sustainable new energetic system. Currently the logistics industry has a large number of vehicles (forklifts, horizontal order pickers, automated guided vehicles AGVs, tow vehicles, captive fleets applied to logistic...) intended to transport goods inside the plant. A problem associated with these logistic vehicles (electric or combustion type) is the charging time and balancing time in the batteries. Solution to the problem approached would be a system that requires a power charging times relatively short (similar to filling in the combustion system) and at the same time that have zero emissions (do not forget that they are operating in a closed environment). Typically, automated guided vehicles and forklifts are operated with leadacid batteries. The replacement of the traction battery with active hybrid power supply provide advantages as longer operating time, no recharging batteries, sizing of the fuel cell can be reduced and energy recovery during braking. Thus, energy management of an Active Hybrid Power System based on $\mathrm{Li}+$ batteries, ultracapacitors and PEM fuel cells, is presented in this paper. Original lead-acid battery can be easily replaced by this new system implemented for industrial vehicles.
\end{abstract}

\section{Keywords}

Hybrid Power System, PEM Fuel Cell, Ultracapacitors, Li+ Batteries, Energy Management, Automated Guided Vehicles, Forklifts, Horizontal Order Picker.

\section{Introduction}

There is a great potential for fuel cells as replacement for lead-acid batteries to run forklifts, automated guided vehicle "AGV" and horizontal order picker due a multiples factors. These parameters include power hybrid system, life-time, refuelling time and labour-savings, overall energy usage, the cost of hydrogen storage and dispensing infrastructure, service/maintenance (task, intervals and equipment), safety/operational training and increase floor space. With the advancements of robotics technologies, the industrial environments are adopting more and more aspects of automation to enhance quality of production and accuracy with better time management. One of these aspects is the use of automated guided vehicle and horizontal order picker systems which is gaining importance in industrial logistics and transportation.

The renewable energies together with other technologies in low $\mathrm{CO}_{2}$ emissions and the efficiency must be the base of the most sustainable new energetic system. The use of the hydrogen for to be able to store the energy generated by means of renewable sources is a technology with one increasing interest inside the society. Its majority implantation would suppose an impulse to the integration of the renewable ones in the electrical European system. The purpose of this new technological approach is to increase the energy efficiency of vehicles and at the same time reduce greenhouse gas emissions (GHG). In the last years, the communication media and organizations, indicate that hydrogen and the fuel cells can be used in all the sectors of industry and economy, offering great quantity of benefits for the environment, energetic market, the home economics, etc... [1], [2]. Between these benefits its can include: high efficiency and zero emissions.

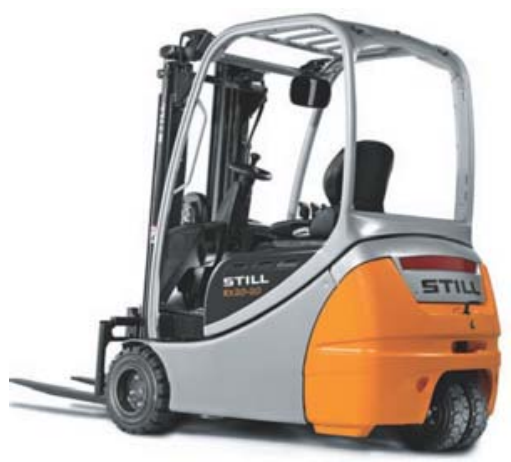

Figure 1. Forklift. An example of industrial vehicle.

Logistics centres currently have a large number of vehicles (forklifts, horizontal order pickers, automated 
guided vehicles, captive fleets applied to logistic...) for the carriage of goods inside the plant. These industrial buildings in most situations have a large area and means of transport must be able to sort and move loads quickly and efficiently. Of these vehicles, the greatest number of times you can see, due to its utility and easy handling, is the forklift or horizontal order picker powered by means of batteries. There are also vehicles that consume fossil fuels, mainly diesel or LPG (Liquefied Petroleum Gas), but the quantity of $\mathrm{C}_{\mathrm{OX}}$ and $\mathrm{N}_{\mathrm{OX}}$ contained in exhaust gases from combustion make them unsuitable to operate in closed environments such as inside a building. In addition, high fuel prices and emissions regulations have increased the development of much more efficient forklifts.

Actually problems associated with electric vehicles are the charging times and balancing batteries, which often fluctuate between 8 and 12 hours during the slow charge. This situation cause unnecessary "delay time" doing that the industrial vehicles are stopped. This it is the reason by that large logistics companies raised the number of transport vehicles. A solution that was not widely accepted, it is the removal and replacement of the batteries during charging and discharging process, mainly due to size/weight of batteries and the need for specialized personnel to realize such operations.

Thus a solution to the problem approached would be a system that requires a power charging times relatively short (similar to filling in the combustion system) and at the same time that have zero emissions (do not forget that they are operating in a closed environment). The solution is to use a fuel cell or active hybrid power system associated with the consumption of hydrogen. Fuel cells are electrochemical devices that, in the presence of a catalyst, transforming the chemical energy of fuel (usually hydrogen) in electricity and water, with a high efficiency $(>50 \%)$, without using moving parts and no emission pollution. Thus, considering the space available in the industrial vehicles for the location of the existing lead-acid batteries and dimensions of the new system based on PEM fuel cell, there wouldn't be problems for adjustment and installation.

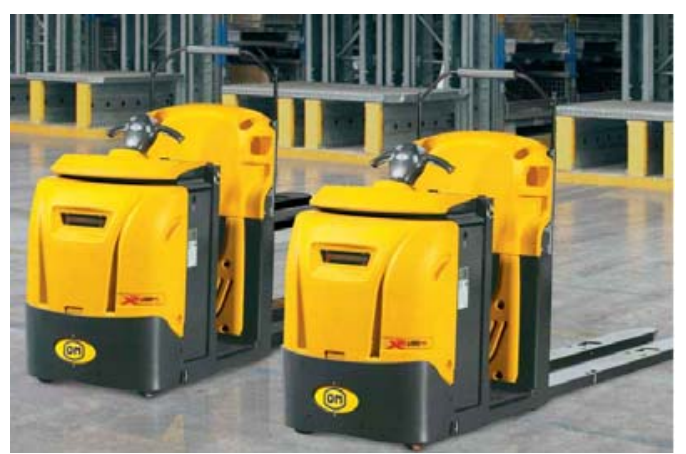

Figure 2. Horizontal Order Picker dedicated to goods movement into industrial environment.

As example of PEM fuel cell system application, Manfred Limbrunner explains that the company ran its first forklift demonstration on a STILL R60-30 for two years at Munich Airport. This hybrid unit has a PEMFC motor of
$18 \mathrm{~kW}$ together with a nickel-cadmium battery. Cargogate GmbH user the STILL forklift at the airport and was able to run a full eight-hour shift with 7 litres of hydrogen gaseous. In 2005 Toyota tested its FCHV-F forklift prototype, featuring a PEM fuel cell stack hybridized with ultracapacitors using a cartridge for on-board hydrogen. To date, some studies [3] have concluded that PEM fuel cells may have economic and operational benefits over conventional internal combustion vehicles and electric vehicles. The objective of the present study is to optimize a hybrid power supply system for a forklift truck; in contrast to previous studies where economic and productivity effects were investigated [4], [5].

\section{Active Hybrid Power System.}

Although recent literature comments on fuel cells are a new emergent energy source, this technology was developed in 19th century. In 1839 sir William Grove assembled the first fuel cell. Since then the fuel cells stack have been used in research and studies. The NASA (National Aeronautics and Space Administration) selected PEM Fuel Cell for the space program in the 1960s, rejecting both nuclear power (higher safety risk) and solar power (higher cost). So that in the past, fuel cells provided power for the Gemini and Apollo missions, at present provide water and electricity to the space shuttle.

At the core of a PEM fuel cell is a membrane that has some unique property; it is impermeable to gases but can transmit protons (Proton Exchange Membrane). This membrane acts as the electrolyte; it is located between the porous conductive electrodes (anode and cathode). Most option promising fuel cell technologies is the Proton Exchange Membrane PEM which uses a platinum catalyst on the anode and polymer membrane in the electrolyte. Electrochemical reactions occur at the catalyst surface in the electrolyte-membrane interface. Hydrogen is fed on one side of the membrane. Protons travel through the membrane, while the electrons move through electrically conductive electrodes and the external circuit. Water is created in the electrochemical reaction and then pushed out of the cell with an excess flow of oxygen [1], [2]. A schematic diagram of fuel cell configuration and basic operating principles are shown in the figure 3 .

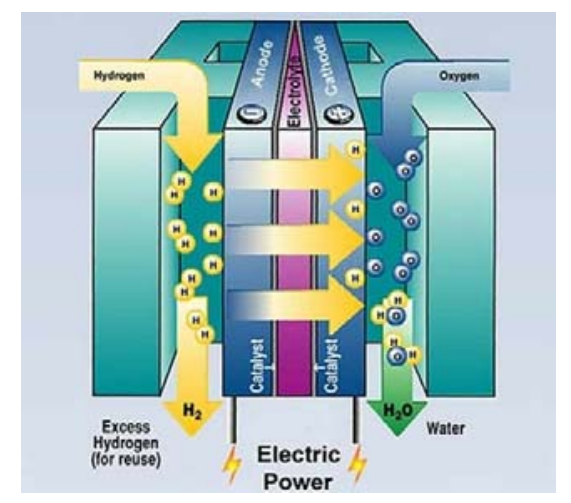

Figure 3. A schematic diagram of cell configuration and basic operating principle in a PEM fuel cell. 
Chemical reactions in fuel cell happen simultaneously on both membrane sides (anode and cathode). The result of these simultaneous reactions is a current of electrons through an external circuit (electrical current in the load). The electrons move from the anode to the cathode through the connected external load. The basic fuel cell reactions are:

Anode: $\mathrm{H}_{2} \rightarrow 2 \mathrm{H}^{+}+2 \mathrm{e}^{-}$

Cathode: $1 / 2 \mathrm{O}_{2}+2 \mathrm{H}^{+}+2 \mathrm{e}^{-} \rightarrow \mathrm{H}_{2} \mathrm{O}$

Combining the previous reaction was obtained the overall reaction. Overall: $\mathrm{H}_{2}+1 / 2 \mathrm{O}_{2} \rightarrow \mathrm{H}_{2} \mathrm{O}$

On the one hand, fuel cells are considered similar to batteries except that fuel is continuously supplied as oxidant, usually oxygen from the air. Fuel cells provide direct current through a non-combustion process. Due to that fuel cells are not a combustion engine; they are not limited by Carnot efficiencies. In general, rechargeable and non-rechargeable batteries, utilize anodes and cathodes solids that contain the chemicals materials used in the electricity generation. Just, fuel cells use anodes and cathodes gas and the fuel is provided from an external source. The hydrogen can be stored as a compressed gas or as a metal-hydride (more security). Thus fuel cells are considered good candidates for automotive applications due to their low operating temperatures and high power density.

In comparison to gasoline, hydrogen has more energy density by mass unit. For example, $25 \mathrm{~kg}$ of gasoline is equivalent a $10 \mathrm{~kg}$ of hydrogen $\left(\mathrm{H}_{2}\right)$. However, $25 \mathrm{~kg}$ of gasoline can be stored in 25 litres whereas the liquid hydrogen needs 125 litres approximately. Moreover, the charge in these devices is realized in seconds whereas lead-acid batteries often require hours, thus potentially benefiting quick-charge applications. So that PEM fuel cells can be charged just before use.

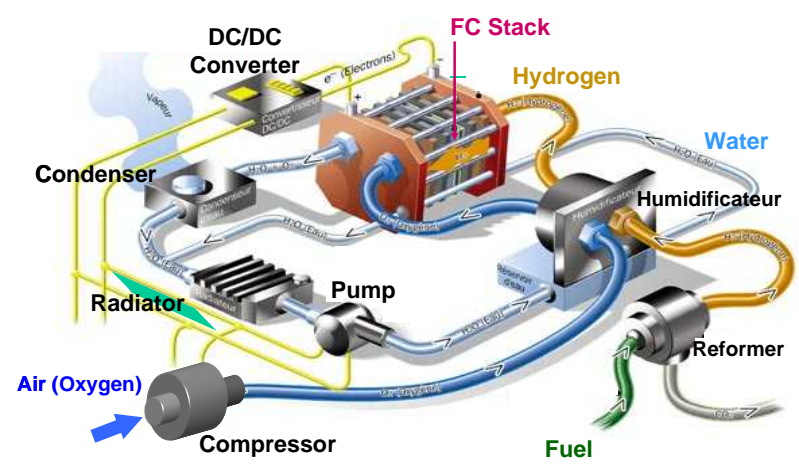

Figure 4. Simplified system of the PEM Fuel Cell system.

These devices produce electrical power through the catalytic reaction of hydrogen oxidation, they have a high efficiency and their by-products are water and heat. However the high cost, low reliability and short lifetime of fuel cells are limiting its massive utilization in real applications. In this context, not only the improvement of the system design, better materials and components, but also new advanced control systems are necessary to achieve costs reduction, faster dynamic responses and optimization of the energy conversion [6].

Figure 4 show some peripheral elements that are required for the operation of the PEM fuel cell stack. Like this a continuous flow of hydrogen $\left(\mathrm{H}_{2}\right)$ and oxygen (air) is needed to obtain electric power from the stack. The PEM cathode is fed with ambient air by means of a blower operating in suction mode. Pure hydrogen, which is stored in a tank, is introduced into the anode. The complete PEM system also consists of an electric subsystem that connects the fuel cells stack to the converter and the load external. Humidifiers are used to maintain their humidity and temperature conditions inside the cell stack, an important issue for PEM membranes.

Typically an automated guided vehicle, horizontal order picker and forklift are operated with lead-acid batteries. The replacement of the traction battery with active hybrid power supply provide advantages as longer operating time, no recharging batteries, sizing of the fuel cell can be reduced and energy recovery during braking. Before designed the hybrid system, the industrial vehicle has that to be characterized in terms of the maximum peak of power during the acceleration and braking process.

Table 1. Comparison of various industrial vehicles models.

\begin{tabular}{|c|c|c|c|}
\hline $\begin{array}{c}\text { Method of } \\
\text { Industrial } \\
\text { Transport }\end{array}$ & $\begin{array}{c}\text { Automated } \\
\text { Guided } \\
\text { Vehicle }\end{array}$ & Forklift & $\begin{array}{c}\text { Horizontal } \\
\text { Order } \\
\text { Picker }\end{array}$ \\
\hline Manufacturer & Savant & Still & OM \\
\hline Model & DF-40 & RX20-15 & Xlogo1 \\
\hline $\begin{array}{c}\text { Traction } \\
\text { Motor (kW) }\end{array}$ & 3 & $2 \times 4,5$ & 3 \\
\hline $\begin{array}{c}\text { Total } \\
\text { Weight (kg) }\end{array}$ & 1591 & 2824 & 1010 \\
\hline $\begin{array}{c}\text { Voltage } \\
\text { Battery (V) }\end{array}$ & +24 & +48 & +24 \\
\hline $\begin{array}{c}\text { Energy } \\
\text { Battery (kWh) }\end{array}$ & 14,4 & 27,6 & 10,1 \\
\hline $\begin{array}{c}\text { Weight } \\
\text { Battery (kg) }\end{array}$ & 557 & 856 & 370 \\
\hline
\end{tabular}

Table 1 shows a comparison among different models assigned to the logistic environments. For example, if it's selected the AGV, the manufacturer provides in his datasheet an average driving power parameter of $1,8 \mathrm{~kW}$ for material movement during an automatic standard operation cycle. Like this the fuel cell system selected for the vehicle should have a power near to this value. On the other hand, maximum acceleration power $(+4,45 \mathrm{~kW})$ and maximum braking power $(-2,97 \mathrm{~kW})$ influence about the dimensioning of the energy hybrid system. Moreover in this case, the compartment assigned for the batteries has dimensions of $800(\mathrm{~L}) \times 350(\mathrm{~W}) \times 705(\mathrm{H}) \mathrm{mm}$ while that battery weight is $557 \mathrm{~kg}$, see AGV in the table 1 . So for example with a hydrogen tank (25 litres) at 250 bars pressure, the driving range is approximately $30 \%$ lower compared to the lead-battery; being its main advantage the low weight of the system. Sometimes the weight 
reduction must be compensated to ensure the traction and stability of the vehicle, depending on the application.

In order to classify different hybrid systems, the so called hybridization degree $(H D)$ is used. According to Jeong, the level can be calculated as follows, [7]:

$$
H D=1-\frac{P_{F C_{-} \max }}{P_{\text {system_max }}} ; 0 \leq H D \leq 1
$$

where $P_{F C_{-} \max }$ is the maximum PEM fuel cell power and $P_{\text {system_max }}$ is the maximum system of power installed. The $H D$ coefficient can adopted values between 0 (pure fuel cell vehicle) and 1 (pure battery vehicle). Each hybrid system consists of a power and energy source. For the theoretical PEM fuel cell, ultracapacitor and battery hybrid system assigned to logistics vehicles as forklift, automated guided vehicles or horizontal order picker, the distribution is as follows:

\section{Energy PEM Fuel Cell $\rightarrow$ average driving power. \\ Power Battery $\rightarrow$ acceleration and braking power. UCaps $\rightarrow$ acceleration and braking power.}

Then it is advisable that the electric power of the PEM fuel cell is equivalent to the average driving consumption. Also there is that to consider the losses in the system (DC-DC converter and leakage current of the battery and ultracapacitors) together with consumptions from the peripheral components. The main purpose of the battery or ultracapacitors is to produce the acceleration power necessary at any time and to store the energy during the braking process. Moreover, the battery must permit the start-up of the PEM fuel cell system. The characteristics and properties of the batteries (mass and volume, power and energy density, life cycles, rechargeable time,...) show that best option are the lithium batteries. These elements will be connected in series.

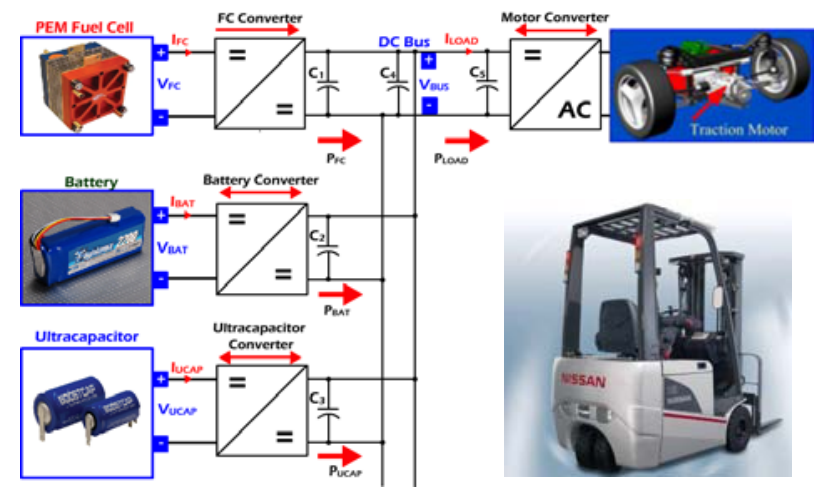

Figure 5. Diagram of the hybrid system consist of PEM fuel cell + battery + ultracapacitor.

Different power converter topologies can be used for power electronic interface between the fuel cell, battery or ultracapacitors and DC bus. Basically, low-voltage and high-current structures are needed due to the electrical characteristics of the elements. A classical buck converter is often selected as fuel cell converter because it can be operated in a continuous condition mode CCM in order to increase his output current. As show in the figure 5, it proposes an active hybrid power system where the battery and ultracapacitors modules are not directly connecting to DC bus. For this reason, there is bidirectional converter in the structure to improve the system efficiency, but it will increase system losses and cost. In this way, for the active hybrid power supply consists of lithium batteries or ultracapacitors, the modules are frequently connected to DC bus by means of a classical bidirectional (two-quadrant) converter (for example: buck-boost, cuk, sepic, zeta). Ultracapacitor current $i_{U C a p}$ and Battery current $i_{\text {Bat }}$, which flow across the energy storage devices, can be positives or negatives allowing energy to be transferred in both directions. It must be noted here that, in this system, the PEM fuel cell is the main power source while the battery and ultracapacitors modules are the secondary power source. These hybrid power supplies are particularly suitable for traffic applications where average power demand is low due to frequent starts and stops of the vehicle.

When comparing the power and energy characteristics of ultracapacitors and batteries, the comparison should be made for the same charge/discharge efficiency. This efficiency depends on the internal equivalent series resistance "ESR" of the devices. For the ultracapacitors, their efficiency is high and the energy lost in heat during each cycle is relatively small. The energy lost in heat in the batteries is much larger amount and thus its extraction costs are much higher. Furthermore, the main disadvantage the batteries is a slow charging time, limited by a charging current; otherwise ultracapacitors can be charged in a short time, depending on the charging current. The objective the ultracapacitors is to absorb the load transient power and peak loads that are required during traction motor acceleration and deceleration.

Energy management of active hybrid power supply has already been studied recently, for example by Thounthong et al. [8], [9] who studied the control and regulation of some hybrid system; by Di Napoly et al. [10] who worked on a hybrid system (ultracapacitors + batteries) for powered vehicles; by Ayad et al. [11] who show the control of a unregulated hybrid system; by Hosseinzadeh et al. [12] who studied the performance of a hybrid system consisting of a PEM fuel cell and lead acid battery or by Burke et al. [6] who propose different topologies applied in electric, hybrid and fuel cell vehicles, among other authors. In this way the literature reveals that previous efforts have focused on the development, design and modeling of hybrid power subsystems, in order to verify its behaviour in function of the operating conditions and the control strategy.

Figure 5 shows the hybrid system approached as energy source for the different logistic vehicles. The diagram represents an active hybrid power system where the power distribution between the PEM cell fuel stack, batteries and ultracapacitors can be actively controlled by the different DC-DC converters. The parameters $p_{F C}, v_{F C}$ and $i_{F C}$ are the power, voltage and current of the PEM fuel cell; $p_{B a t}, v_{B a t}$ and $i_{B a t}$ are the power, voltage and current of the lithium battery; $P_{U C a p}, v_{U C a p}$ and $i_{U C a p}$ are 
the power, voltage and current in the ultracapacitor; $P_{\text {Load }}$, $v_{\text {Bus }}$ and $i_{\text {Load }}$ are the load power, dc bus voltage and load current, respectively. The current $i_{\text {Load }}$ is the consumption of the vehicle traction motor, which can be $i_{\text {Load }}>0$ during the acceleration time and $i_{\text {Load }}<0$ in the braking process.

As shows the figure 5 it is important that the battery and ultracapacitors operate in a partial state of charge in order to store the maximum energy possible during the braking process of the vehicle [13]. A bidirectional buck-boost DC-DC converter helps during the rechargeable process of the components. This require a control strategy which must calculate at all time the control signal for the operation mode in the converters depending on the energy in battery, ultracapacitors and PEM fuel cell together with the current requested by the traction motor [14], [15]. Therefore the original lead-acid battery can be easily replaced by this new system implemented for industrial vehicles (as can be forklift, horizontal order picker, automated guided vehicle, tow vehicle, etc...).

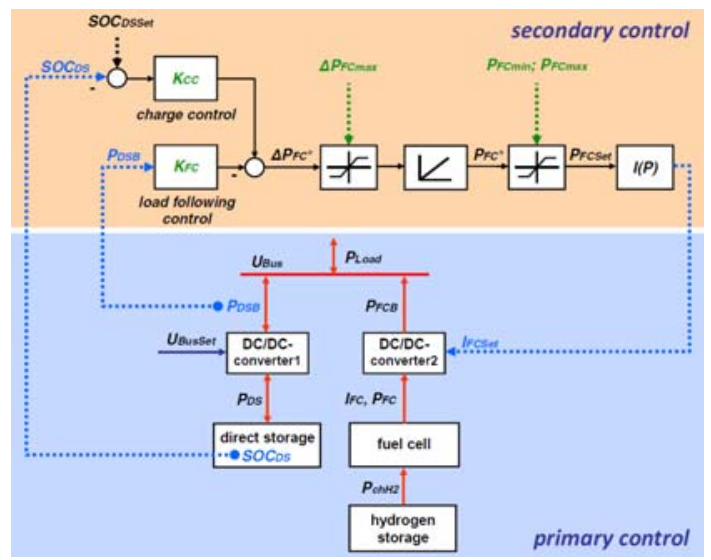

Figure 6. Diagram energy management, voltage and current bus control.

The control strategy of the active hybrid power system is shown in figure 6 . The advanced control is based on the demand for the average power of the vehicle. As can be seen in the diagram, the control variables acting on the hybrid energy storage system HESS (charge/discharge mode of batteries and ultracapacitors) are $v_{\text {Bus }}$ and $i_{\text {Load }}$. This control strategy provides a more efficient use of the ultracapacitors and $\mathrm{Li}+$ batteries instead of the fuel cell system. However, the second control strategy ensures the efficiency of the PEM fuel cell. The main objective of this control technique is to minimize the hydrogen consumption. Although it is necessary to guarantee the different current peaks demanded by the vehicle. PEM fuel cell lifetime is enhanced if its load fluctuations are reduced, and if frequent starts and stops of the fuel cell are avoided.

\section{Discussions and Conclusions.}

PEM Fuel cells are appropriated to generate electrical power with high efficiency, low operation noise and no emissions. Fuel cells are characterized by easy handling and unproblematic refuelling. Thus these devices can be attractive for various applications, for example as replacements for batteries or accumulators in industrial environments or electrical vehicles applications (for example captive fleet applied to logistic).

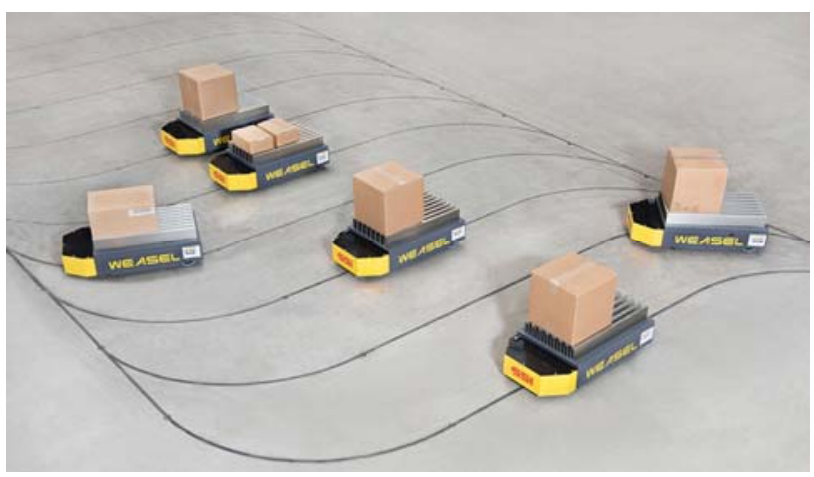

Figure 7. "Weasel” (SSI Schaefer) a small automated selfguided vehicle to perform the internal transport tasks in the warehouses.

In this paper, it is discussed that an active hybrid power system has the potential to compete with the methods generally used in traction system for forklifts, automated guided vehicles AGVs, horizontal order pickers and tow vehicles in industrial environments. Replacing the leadbattery of these vehicles by an active hybrid power supply based on a PEM fuel cell + ultracapacitors or lithium battery system provides some advantages such as faster refuelling, constant performance, increased availability and extended operating times. In other words, productivity and flexibility of vehicles are increased. Figures 7 and 8 show several self-guided vehicles applied in an industrial environment.

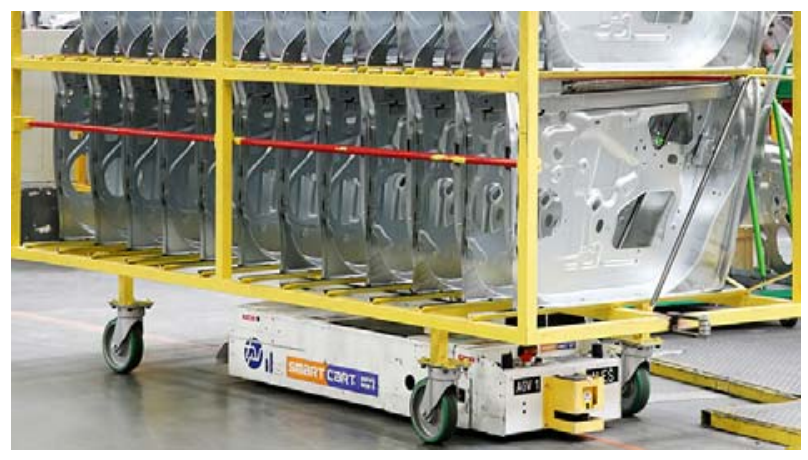

Figure 8. Automated Guided Vehicle moving chassis components in the automotive industry.

This paper demonstrates the suitability of hybrid electric systems to power supply forklift and presents an effective hybrid propulsion system. It was also shown that the space required by the fuel cells system is not bigger that the existing space in battery box. Due to the high fluctuating load profile, the solution proposal is an active hybrid system formed mainly by hydrogen PEM fuel cell stack connected via buck converter and ultracapacitors and batteries connected by means of a bidirectional buckboost converter. There's no doubt about it for the hybrid system operate correctly, it is important to have an energy management strategy to control the current flow between the different components of storage energy in 
order to maintain the state of charge of the energy storage elements (ultracapacitors or batteries) on a level constant.

Lead-acid storage batteries are the oldest technology, although they are less expensive. This type of batteries are safe, widely used and obtain energy densities about 30$50 \mathrm{Wh} / \mathrm{kg}$ (low energy/weight ratio) a relatively long shelflife. To summarize, ultracapacitors and the lithium batteries must be operating in partial state of charge (SOC) in order to store the maximum energy during the braking process. Just will be these energy storage devices that they can provide the power necessary during the acceleration process of the vehicle. Thus, the acceleration parameter is not a critical factor.

Performance and reliability are an important part of any design. In the past the Pb-acid battery has generally been the predominant solution. Today there are many more options to solve the problem of energy storage including but not limited to: advanced technologies of batteries ( $\mathrm{Li}+$, NiMH, NiCd...), PEM fuel cell, flywheels, ultracapacitors, etc. Figure 9 shows a comparison between the different energy storage technologies presented. In order to clarify their choice a qualitative analysis of their properties has been developed. Among the parameters can be highlighted the energy density, power density, operating temperature range, price per kWh, efficiency, number of cycles, cell voltage, recycling, etc. Therefore it is easy to contrast the autonomy, energy density (Wh/kg - Wh/l) and even its energy cost $(€ / \mathrm{Wh})$ in the different storage technologies developed.

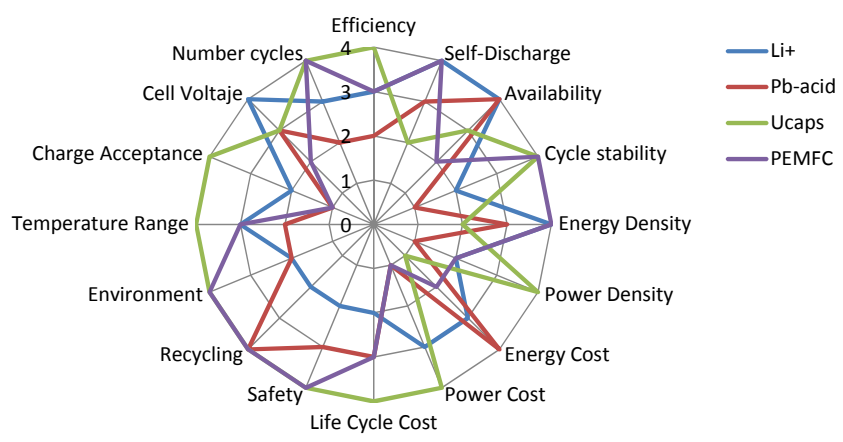

Figure 9. Comparison of specifications on different energy storage technologies used in logistics vehicles.

\section{Acknowledgement}

This work was supported by the Ministerio de Economía y Competitividad of the Spanish Government under research Project ENE2013-48517-C2-1-R.

\section{References}

[1] Barbir F. "PEM Fuel Cells; Theory and Practice". Elsevier Academic Press, New York 2005.
[2] Dowling Kevin. "Power Sources for Small Robots". Field Robotics Center. Carnegie Mellon University. Pittsburgh. Jan 1997. Report CMU-RI-TR-97-02.

[3] Kim S., Choi S., Lee J., Hong S. and Yoon J. "A study of hybrid propulsion system on forklift trucks". World Electric Vehicle Symposium and Exhibition (EVS27). November 2013, Barcelona (Spain); pp.: $1-8$.

[4] Elgowainy A., Gaines L. and Wang M. "Fuel-cycle analysis of early market applications of fuel cells: Forklift propulsion systems and distributed power generation". International Journal of Hydrogen Energy. May 2009, Volume 34, Issue 9, PP.: 3557-3570.

[5] Renquist J.V., Dickman B. and Bradley T.H. "Economic comparison of fuel cell powered forklifts to battery powered forklifts". International Journal of Hydrogen Energy. September 2012, volume 37, issue 17, pp.: 12054-12059.

[6] Burke A.F. "Batteries and ultracapacitors for electric, hybrid and fuel cell vehicles". Proceeding of the IEEE, volume 95, issue 4, pp 806 to 820. April 2007.

[7] Jeong K.S. and Oh B.S. "Fuel economy and life-cycle cost analysis of a fuel cell hybrid vehicle". Elsevier Science Direct. Journal of Power Sources 2002, volume 105, pp 58 to 65.

[8] Thounthong P., Chunkag V., Setthakul P., Davat B. and Hinaje M. "Comparative Study of Fuel-Cell Vehicle Hybridization with Battery or Supercapacitor Storage Device". IEEE Transaction on Vehicular Technology, volume 58, issue 8. October 2009.

[9] Thounthong P., Raël S. and Davat B. "Test of a PEM fuel cell with low voltage static converter". Elsevier Science Direct. Journal of Power Sources 2006, volume 153, pp 145 to 150

[10] Di Napoli A., Crescimbini L., Solero G., Pede G. Lo Banco G. and Pasquali M. "Ultracapacitor and Battery storage system supporting fuel-cell powered vehicles" Proceeding of the 18th International Electric Vehicle Symposium. Berlin (Germany) 2001.

[11] Ayad M.Y., Pierfederici S., Raël S. and Davat B. "Voltage regulated hybrid DC power source using supercapacitors as energy storage devices". Energy Conversion Management, volume 48, issue 7, pp 2196 to 2202. July 2007.

[12] Hosseinzadeh E., Rokni M., Advani S.G. and Prasad A.K. "Performance simulation and analysis of a fuel cell/battery hybrid forklift truck". International Journal of Hydrogen Energy. April 2015, volume 38, issue 11, pp.: 4241-4249.

[13] Pesaran A., Zolot M., Markel T. and Wipke K. "Fuel cell/Battery hybrids: an overview of energy storage hybridization in fuel cell vehicles". Proceeding of the 9th Ulm Electrochemical Talks. Ulm (Germany) 2004.

[14] Gauchia L., Bouscayrol A., Sanz J., Trigui R. and Barrade P. "Fuel Cell, Battery and Supercapacitor Hybrid System for Electric Vehicle: Modeling and Control via Energetic Macroscopic Representation". IEEE Vehicle Power and Propulsion Conference. September 2011, Chicago, United States. <hal-01218789>.

[15] Farhadi M. and Mohammed O. "Energy Storage Technologies for High-Power Applications". IEEE Transactions on Industry Applications. Volume: 52, Issue: 3 June 2016; pp.: 1953 - 1961. 